\title{
DEMOGRAPHIC TRENDS AND THE EDUCATIONAL SYSTEM OF THE REPUBLIC OF SRPSKA
}

\author{
Stevo Pašalić́ ${ }^{1}$, Zoran Mastilo', Aleksandar Đurić1 ${ }^{1}$, Duško Marković ${ }^{2}$
}

date of paper receipt:

date of sending to review:

date of review receipt:

23.04.2020.

26.04.2020.

16.05.2020.

Original Article

doi: 10.2478/eoik-2020-0007

UDK: 314.83:314.18]:371.39

${ }^{1}$ University of East Sarajevo, Bosnia and Herzegovina

${ }^{2}$ Employment Bureau of the Republic of Srpska, Bosnia and Herzegovina

\begin{abstract}
The subject of this research are the demographic trends and the educational system of the Republic of Srpska. The aim of the research is to define the concepts required to comprehend the demographic trends and to explore their implications for the educational system of the Republic of Srpska. In order to establish sustainable development in the Republic of Srpska, education being a key component therein, it is necessary to perceive its demographic resources in order to create an educational system. By means of empirical research with a presentation of results through factor and cluster analysis, generated quantitative and qualitative indices of demographic resources, particularly in the educational system. The Republic of Srpska as a whole belongs to type $\mathrm{D}$, featuring poor demographic resources and characteristics, as well as prominent demographic disparities regarding spatial development. However, in order to increase the coverage, relevance and efficiency of completion of the education process, it is necessary to determine the strategic commitments to be accomplished together with certain quantitative demographic indicators of the achievement level (educational coverage of different generations). Demographic changes will pose a major challenge for policy makers and to the society in general across the upcoming decades and will require shaping new economic, tax, health, pension, educational, social, family and other policies that affect demographic changes. The research endeavour in this paper focuses on that very aspect, together with the respective applicative capabilities.
\end{abstract}

\section{Keywords:}

demographic resources, educational system, school network

JEL: I2, J1 


\section{INTRODUCTION}

In addition to its previously mentioned subject, the purpose of this paper is to answer several specific questions: To what extent do demographic trends dictate a decrease in the number of pupils and students in the Republic of Srpska? How can the educational system maintain economic viability, given the continuous decline of pupils and students while experiencing the same number of (or even more) teachers? How to rationally utilise the excess space in the educational system facilities resulting from the decrease in the number of pupils and students? How can the use of modern technologies assist in rationalising the cost of teaching?

The consequences of negative demographic processes in the Republic of Srpska are reflected in the creation of population-limiting frameworks in education, in the formation of the working contingent, in low economic activity and low levels of development. Therefore, speaking in terms of space, the majority of municipalities/cities in the Republic of Srpska belongs to the demographically jeopardized area.

The aim of this research is to evaluate the demographic resources of the municipalities/cities of the Republic of Srpska by means of demographic indicators, given the distinguished demographic trends, and then to consolidate the consequences of demography in the educational system of the Republic of Srpska.

For more than two decades, there has been a steady decline in the overall population of the Republic of Srpska as a result of natural depopulation, insufficient fertility level to replace generations of emigrants, as well as aging population. The aforementioned reasons are the result of continuous demographic changes occurring in the past, only to be intensified at the end of the 20th and in early 21st century.

Dominant negative demographic trends of fertility decline in Srpska, natural and total depopulation, negative migration balance, as well as very prominent aging of population have influenced the emergence of an increasing number of demographically exhausted and extinct settlements.

The development of the population of the Republic of Srpska with its very diverse spatial characteristics is ailed by the issues that lead to undesirable demographic, economic and social consequences. There are great variances in the level of population recovery in individual areas (municipalities and cities), which is a direct consequence of different trends, such as birth rates and death (mortality) rates, as well as of internal and external migration, which depends on economic, social, cultural and educational development.

Adverse demographic processes have led to a decrease in educational, and thus in human assets, as the foundation of socio-economic development. In highly depopulated areas, only a small population remained living in unfavourable prospects (biological, educational...), which is a limiting factor for further development.

The transformation of society towards a knowledge economy requires more radical changes in education of the Republic of Srpska.

The countries and economies that feature the so-called post-demographic transition ("second demographic transition") suffer from low fertility rates, near completion of demographic transition resulted in the dominance of the elderly population, with less than $45 \%$ of the population aged under 30 (in Bosnia and Herzegovina, that percentage is 35\%, in the Republic of Srpska, it is 33\%), and up to $1 / 4$ population aged over 60 (in Bosnia and Herzegovina - 20\%, in the Republic of Srpska 25), this indicates the existence of the so-called mature population structure which is unfavourable for economic growth and development.

Speaking of the developed countries, the demographic transition has played an important role in the emergence of modern growth, as it has enabled economies to convert much of their capital accumulation and technological progress into per capita income growth. 


\section{METHODOLOGICAL FRAMEWORK OF RESEARCH}

The methodology of this paper is based on GIS analysis in deriving the Demographic Resources Index (ider). The paper includes the Demographic Resources Index derived from demographic variables referring to population structure.

A methodological framework for calculating the Demographic Resources Index was proposed by Nejašmić and Mišetić (2010), whereas the procedure for its implementation will be elaborated herein.

An important component for applied demographic research is the source of data, that is, highquality foundations for geographic information system (hereinafter referred to as GIS). It is crucial to establish continuous data sources that are minimally dependant on the census.

A combination of multi-method research is the preferred mode of operation in demographic analyses. It is a condition where a method is dependent on another, all for the purpose of an effective research concept (McKendrick, 1999).

Technological developments have also led to the development of GIS, which has greatly expanded the possibilities and scope of demographic analysis and the application of research results. Demographic analyses can be performed at several spatial levels (in our case - the level of the Republic of Srpska and at the lower level encompassing various municipalities and cities).

According to the above methodology, the calculation of the Demographic Resources Index includes two basic components: the demographic index (idem) and the education index (Io), as well as the population as a correction coefficient.

This demographic research is based on the interconnection between GIS and demographics. In addition to the high-quality data collected, the research plan also included a methodological approach (empirical assessment) and the establishment of a space-time framework for the research. The methodological model "sustendemo" (Roca 2011; Roca \& Leitão 2006), encompassing two fundamental dimensions - quantitative and qualitative, was applied to the study of demographic sustainability. The quantitative dimension consists of both components (natural increase and migration) of the total growth as well as of the age structure of the population. The qualitative dimension reflects the socio-economic characteristics of the population, such as education, student utilization, professional qualifications and activity.

The analysis from the survey includes 63 municipalities and cities of the Republic of Srpska (According to census from the year 2013, there is no data for the municipality of Stanari), mainly in the post-census period (after 2013), based on the data of the Statistical Office of the Republic of Srpska (population estimate and vital statistics data, education statistics, etc.). The paper included fifteen (15) variables depicting the condition, dynamics of the quantitative and qualitative dimensions of demographic sustainability. The statistical model used to determine the spatial typology was the factor and cluster analysis (Maroco 2003; Rencher 2002) and (Nejašmić, I., Mišetić, R.2010).

Upon applying these demographic variables for the purpose of calculating the components of the synthetic Demographic Resources Index, a correction of the obtained values was performed based on the correction coefficient $(\mathrm{k})$. The determination of the correction coefficient values for each municipality and city territory is based on the basic principles of the $\mathrm{z}$-standardization process, that is, the transformation of a numerical random variable Pn (demographic mass) into a standardized normally distributed random variable, Zpn, with arithmetic mean of 0 and standard deviation of 1 . The results of demographic research are directly applied in spatial planning, tasked to achieve harmonious economic and social development, including the educational system of the Republic of Srpska as well. 


\section{RESEARCH RESULTS AND CORRESPONDING DISCUSSION}

Negative and structural demographic trends are becoming an increasingly severe threat to social stability and economic development, which has a significant impact onto education as a whole. The age cohorts 0-24 form a pre-educational and educational contingent about to experience major transformations in the distant future as a result of demographics. This is posed as a major issue in the educational system, which inevitably needs to adapt to these trends.

\subsection{DEMOGRAPHIC TRENDS AND DEMOGRAPHIC RESOURCES OF THE REPUBLIC OF SRPSKA}

In the aftermath of World War II, Bosnia and Herzegovina suffered from strong emigration, the most evident one compared to any of the other regions of the former Yugoslavia. The reasons are to be found in economic and demographic factors. Economic and demographic circumstances in Bosnia and Herzegovina incited the population to emigrate.

In the early 1990s, Bosnia and Herzegovina entered one of extraordinary stages of its socio-political and demographic development. The war occurring within its territory, together with post-war and transitional challenges and their inevitable impact on social events and processes, have particularly shaken the demographic trends. The war in Bosnia and Herzegovina in the early 1990s triggered very intense emigration. Migration losses due to the war (1992-1995) amounted to 527,000 people (Pašalić, 2012).

According to the data on the number of immigrants from the period between censuses 1991-2019, vital statistics data, as well as the application of the vital statistics method for migration evaluation, it is possible to make an estimate that from 1991 to 2019, approximately 1,281,874,266 people emigrated from Bosnia and Herzegovina, which amounted to $29 \%$ of its population (1991). This emigration was mainly directly caused by the war (refugees), but also by economic situation. The highest average annual negative migration balance was registered in Bosnia and Herzegovina in $1992-95$ (-51.8 per population of 1000), with a total loss of one million people. Half of that loss was compensated between 1995 and 2000, with the numbers being close to 500,000, whereas the remaining portion that remained outside of Bosnia and Herzegovina amounted to 527,000 (Pašalić, 2012).

Table 1. Demographic losses in Bosnia and Herzegovina (1991-2019)

\begin{tabular}{|l|l|l|l|l|l|l|l|}
\hline & $\begin{array}{l}\text { Population } \\
1991\end{array}$ & $\begin{array}{l}\text { Population } \\
2013\end{array}$ & $\begin{array}{l}\text { Non- } \\
\text { resident } \\
2013\end{array}$ & $\begin{array}{l}\text { Population } \\
\text { growth } \\
2014-2019\end{array}$ & $\begin{array}{l}\text { Net } \\
\text { migration } \\
2014-2019\end{array}$ & $\begin{array}{l}\text { Population } \\
2019\end{array}$ & $\begin{array}{l}\text { Total } \\
\text { Depopulation } \\
2019 / 1991\end{array}$ \\
\hline $\begin{array}{l}\text { Bosnia and } \\
\text { Herzegovina }\end{array}$ & $4,377,033$ & $3,531,159$ & $-196,000$ & $-43,423$ & $-240,000$ & $3,051,736$ & $-1,325,297$ \\
\hline $\begin{array}{l}\text { The Republic of } \\
\text { Srpska }\end{array}$ & $1,558,387$ & $1,228,423$ & $-58,081$ & $-31,013$ & $-81,600$ & $1,057,729$ & $-500,658$ \\
\hline $\begin{array}{l}\text { The Fed. of } \\
\text { Bosnia and } \\
\text { Herzegovina }\end{array}$ & $2,731,019$ & $2,219,220$ & $-133,019$ & $-8,382$ & $-152,400$ & $1,925,419$ & $-805,600$ \\
\hline Brčko District & 87,627 & 83,516 & $-4,900$ & $-4,028$ & $-6,000$ & 68,588 & $-19,039$ \\
\hline
\end{tabular}

Source: Pašalić, S. (2019): Vital statistics method and estimate

Depopulation is a demographic phenomenon affecting spatial development. The population of the Republic of Srpska is declining and many local spatial units have been affected by the depopulation process. The combined effects of low fertility, exodus of young people and the unfavourable age structure led to the process of extinction of certain areas in Srpska. 
The most economically underdeveloped local communities are the ones that are most affected by the total depopulation. What is common to these spatial units is the fact that they are predominantly rural areas with weakened reproductive potential and emigration areas. In the 1990s, the combined effects of fertility and war-induced emigration accelerated depopulation, which is often forgotten in certain demographic analyses.

Natural population growth is a major element in the survival of a nation. Once it becomes negative, if there is no immigration, the population decreases. If the annual rate of natural growth of population is $-4,61 \%$ (the Republic of Srpska $-4,53 \%$ ), then the population of a certain territory shall be halved in 150 years. The rate of $-9,2 \%$ corresponds to a period of 75 , and the rate of $-13,77 \%$ o to a period of 50 years. If the natural population growth rate is $-27,35 \%$, then the population will be halved in 25 years, i.e. by a single generation gap. Conversely, if the natural population growth rate is, for example $35,26 \%$, then the population will double in 20 years. The annual growth rate of $6,96 \%$ corresponds to a doubling period of 100 , a rate of $3,47 \%$ o to 200 and a rate of $1,39 \%$ o to a period of 500 years (The above annual rates for doubling, or halving the population were calculated based on the templates provided in the abstract of this paper.).

Figure 1. Spatial aspect of depopulation of municipalities and cities of the Republic of Srpska, 2018.

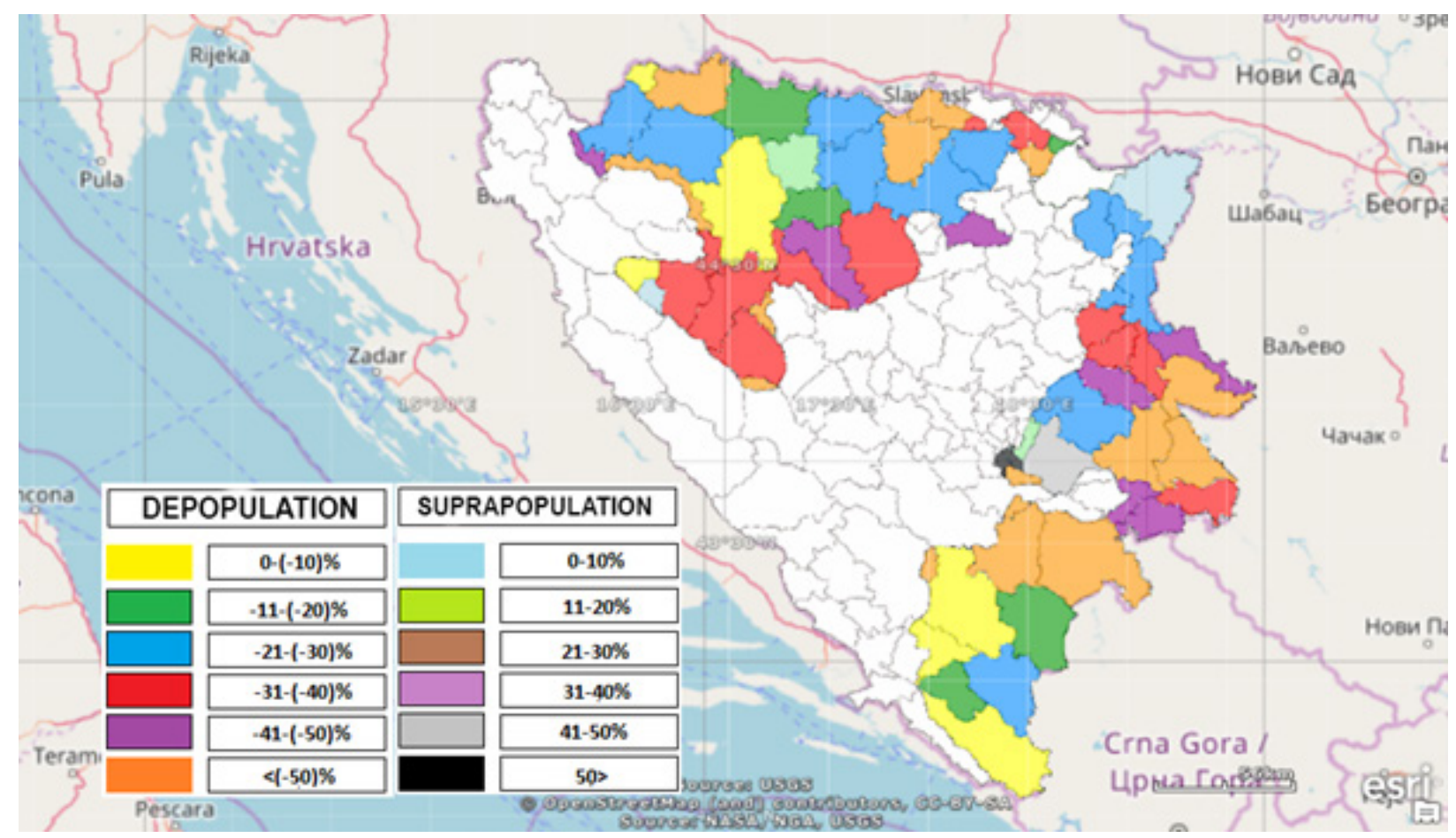

Source: Author's own processing with the use of GIS (geographic information system software)

In the period 1996-2018, the overall birth rate in the Republic of Srpska has been steadily declining and in 2011 the number of births dropped below 10,000 for the first time. Over the sixteen-year period, ranging from 2002 to 2018, merely based on a negative natural growth rate, the population of the Republic of Srpska decreased by $2.7 \%$. The negative natural population growth rate is conditioned by a sharp decline in the birth rate in the first decade of the 21st century and an increase in the mortality rate. The highest registered natural growth rate increase occurred in 1997, while the lowest absolute value was registered in 2015 (-5.702), and in 2018 amounting to -5.324 $(-4.53 \%)$. 
Figure 2. Average number of births in cities and municipalities of the Republic of Srpska (2014-2018)

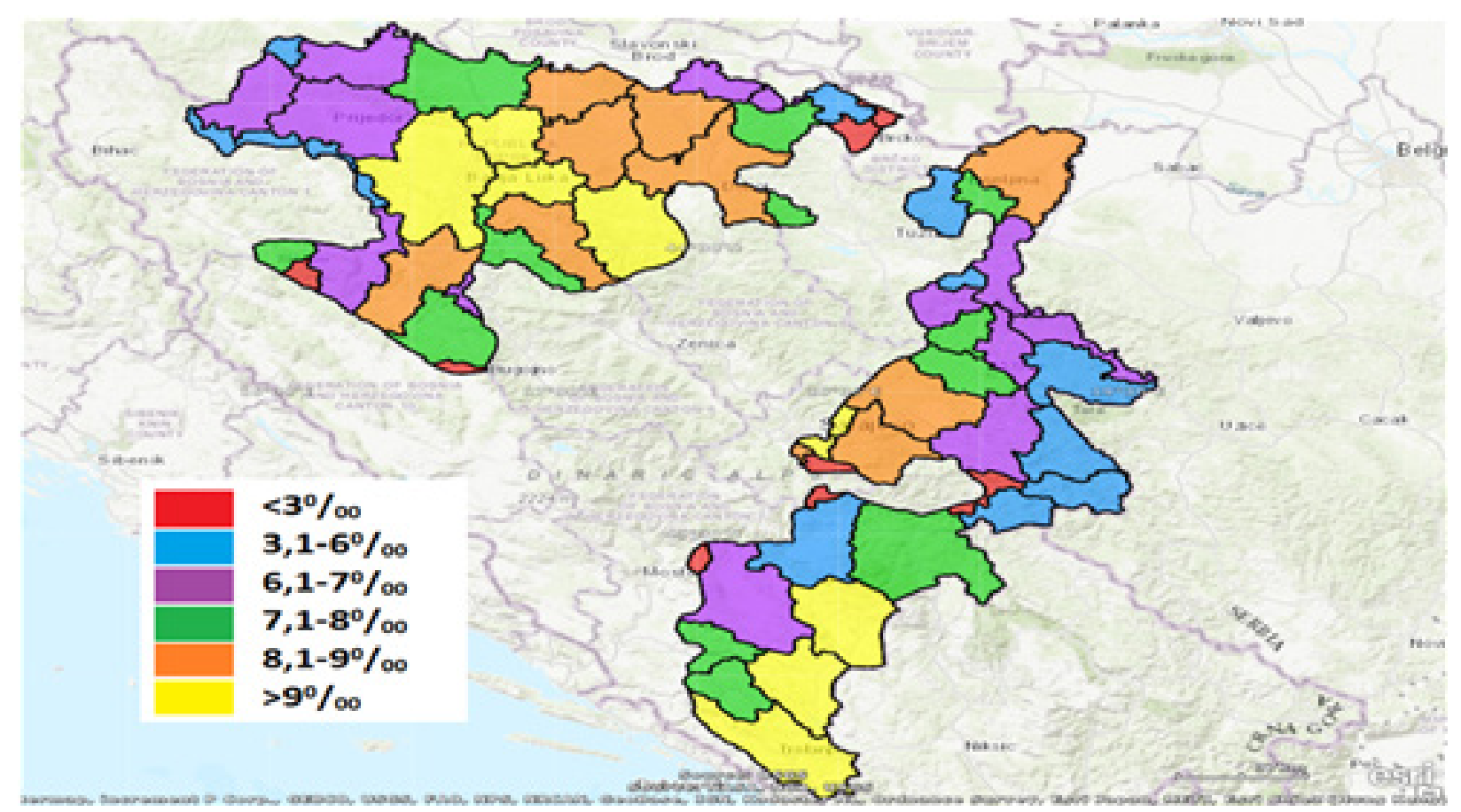

Source: Author's own processing using GIS, 2019, based on vital statistic data, Statistical Office of the Republic of Srpska, Banja Luka, 2019.

An analysis of the general birth rate shows that the area of the Republic of Srpska is classified as a low-birth rate area. The gross fertility rate is very low, which is a consequence of family planning, ever more popular life as a single person, post-war trauma, resettlement and refugee processes, as well as socio-economic situations, psychological and other factors.

The Republic of Srpska's educational system in 2018/2019 (elementary education, secondary schools, higher education) is attended by generations born from 1995 to 2012 (by 1 September). All generations combined, there were 196,634 births, with 157,085 pupils and students included in the education system. The overall educational coverage of generations amounts to $79.9 \%$. The dropout rate is about $20 \%$. However, a more relevant indicator of coverage is classification by each generation of births (in a given year) and by segments of the education system they attend. Elementary education is the only one mandatory by law, so it is expected that the coverage is nearly $100 \%$. Other segments of education are not legally required, therefore causing that the coverage is less compared to elementary education, both in secondary schools and in higher educational institutions.

The general mortality rate depends on the age structure of the assessed population, not just on the intensity of deaths. An example of such disadvantage is that an area that features a majority of the elderly population as a whole will, as a rule, have a higher mortality rate than the evaluated area with the predominant young population (Pašalić, 2017).

Important indicators that influence the total natural change in population are the general fertility rate, the age-specific fertility rate and the total fertility rate.

The general fertility rate (ff) shows the number of live births per 1,000 women in their fertile period (effective birth quota in the fertile period). The age structure is crucial, as the age interval 15-49 may be comprised of a very distinctive age composition. Specific fertility rates are used for fertility analysis by a woman's age, the indicators of which reflect the fertility age structure. The highest fertility rate in 2017 was registered in the age group of 25-29 years, 86,26\%o).

Total Fertility Rate (SUF) - is the average number of children per woman, which is no longer clearly differentiated into the developed and underdeveloped part of the world. 
Figure 3. Average number of deaths in municipalities and cities of the Republic of Srpska, 2018.

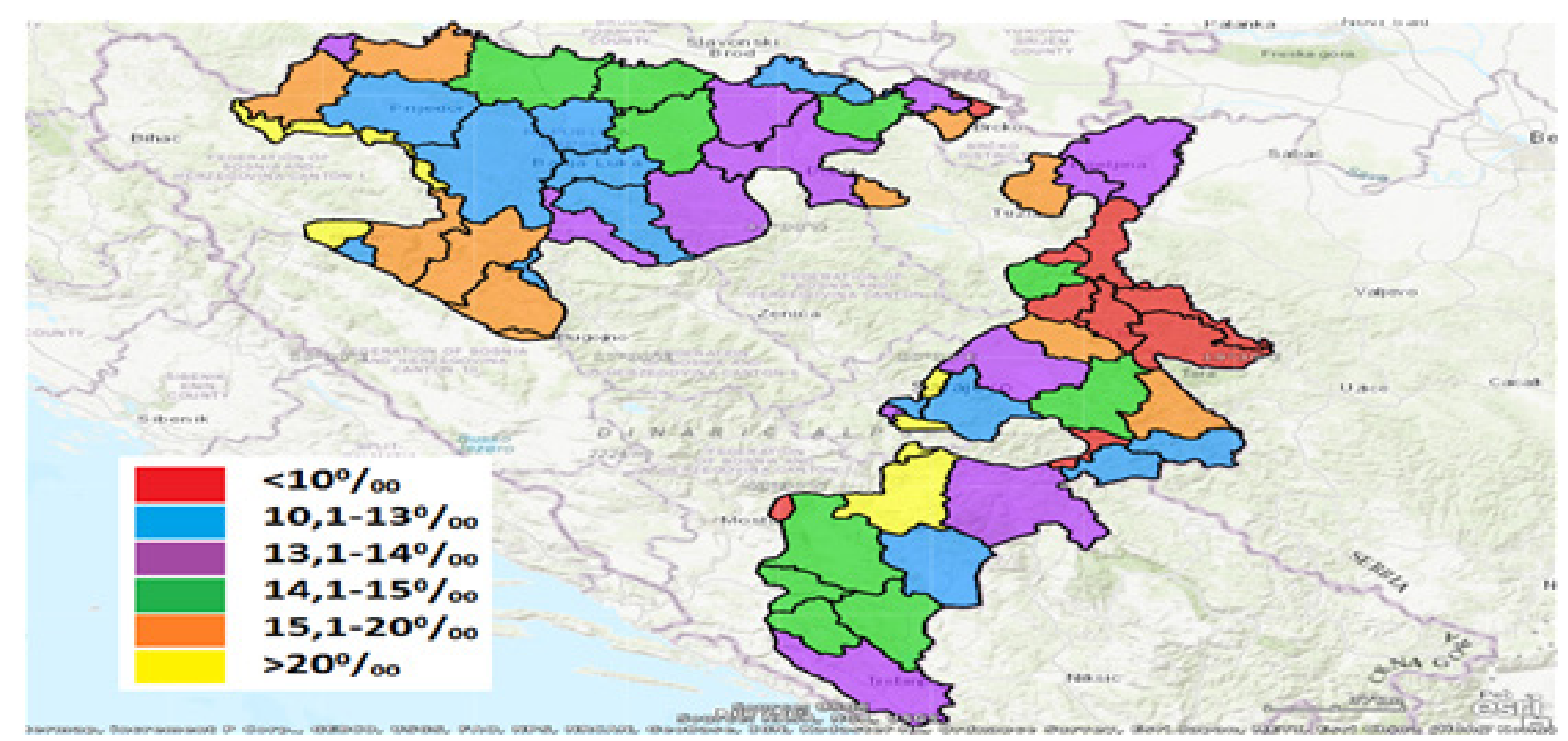

Source: Author's own processing using GIS, 2019, based on vital statistic data, Statistical Office of the Republic of Srpska, Banja Luka.

An SUF of 2.1 is considered to be a cut-off value below which no simple reproduction (replacement of generations) is ensured.

Figure 4. Vital Index of Municipalities and Cities in the Republic of Srpska, 2018.

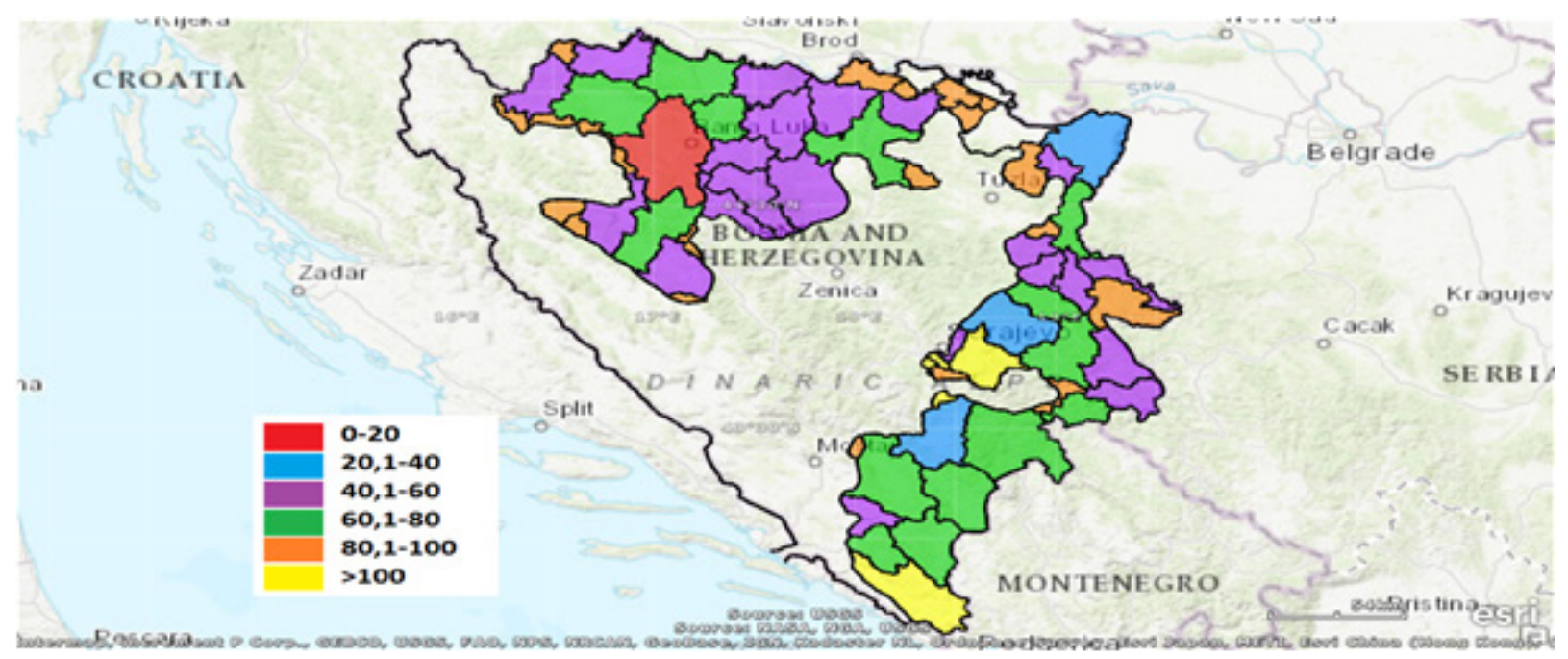

Source: Author's own processing using GIS, based on vital statistic data, Statistical Office of the Republic of Srpska, Banja Luka, 2019.

Analysing birth rates from 1996 to 2018, the highest number of births was registered in 1999 $(13,995)$. From 2003 to 2010, the number of births ranged from 10,100 to 10,600. As of 2011 and by 2018 , the number of births dropped below 10,000 annually, i.e. an average of about 9,500, with a very likely downward trend. Data on the number of births clearly indicate a downward trend in young (school-age) generations. The downward trend in the number of young generations has direct implications for the educational system of the Republic of Srpska, i.e. the tendency of diminishing birth rates clearly shows the extent and correlation of how demographic trends affect the decline in the number of pupils and students. Thus, the reduced contingents of pupils and students in education is, first and foremost, a consequence of demographics. 
Table 2. Total Fertility Rate of the Republic of Srpska (TFR) 2018.

\begin{tabular}{|c|c|c|c|}
\hline Age & Number of births & Number of women & $\mathbf{f}_{\mathbf{x}}$ \\
\hline $15-19$ & 220 & 28,384 & 7,75 \\
\hline $20-24$ & 1906 & 33,598 & 56.73 \\
\hline $25-29$ & 2889 & 32,074 & 90.07 \\
\hline $30-34$ & 2949 & 37,777 & 78.06 \\
\hline $35-39$ & 1348 & 39,627 & 34.02 \\
\hline $40-44$ & 238 & 39,144 & 6.08 \\
\hline $45-49$ & 18 & 36,995 & 0.49 \\
\hline$\sum$ & 9568 & 247,599 & 273.20 \\
\hline $273.2 \mathrm{~h} 5=1,366$ & $1,3661,000$ & $f_{u}$ & $\mathbf{1 . 3 6}$ \\
\hline
\end{tabular}

Source: Author's own processing based on vital statistic data, Statistical Office of the Republic of Srpska, 2018

The total fertility rate as opposed to the general fertility rate does not depend on the age structure. It is obtained as the sum of specific fertility rates for all ages of the fertility period relating to an individual calendar year.

The total fertility rate indicates the number of live births per woman, provided that the fertility by age from the observed year is the same throughout the entire reproductive life. It is used to compare fertility levels for different populations and time periods.

Unlike the total fertility rate that follows the fertility of a generation in a calendar year, a cohort analysis follows the fertility of a generation of women. If this generation is more than 50 years old and will no longer engage in childbirth, the average number of children per woman from that cohort indicates final fertility.

The assessment of the biological reproduction potential of the population, particularly from the perspective of estimating the magnitude of replenishment and renewal of generations, requires the analysis of demographic and social indicators for reproduction.

In order to ensure the replacement of generations, the total fertility rate should be at the level of fu $=2.1$ child per woman. Total Fertility Rate in the Republic of Srpska amounted to amount 1.36 in 2018. Such rate shows that no simple reproduction has been ensured in the Republic of Srpska, as the given rate is $37 \%$ lower than the minimum, whereas the birth rate deficit amounts to 0.74 .

The data indicate that the decline in general birth rates and fertility rates was influenced by the decrease in age-specific fertility of women in certain age groups, especially in those that mark the highest potential biological fertility (20-29). In addition to the aging of the fertile contingent, changes in the reproductive behaviour of the population, expressed in shifting the focus of fertility to older age groups (of over 30 years of age), have played a significant role in reducing the volume of population reproduction in the Republic of Srpska.

The transition of fertility took place more intensively than other transition processes, as did changes in the total fertility rate relative to other indicators of development.

Table 3. Vitality Index of the Republic of Srpska, 2018.

\begin{tabular}{|c|c|c|c|c|c|c|c|}
\hline $\mathbf{0 - 1 4}$ & $\mathbf{2 0 - 3 9}$ & $\mathbf{6 5}+$ & $\mathbf{P 2 0 - 3 9}$ & $\begin{array}{c}\text { Is=(65+/0- } \\
\mathbf{1 4}) * \mathbf{1 0 0}\end{array}$ & Rate $\boldsymbol{m}$ & $\boldsymbol{f}$ & $\boldsymbol{I}_{\boldsymbol{v}}$ \\
\hline 156105 & 296015 & 218373 & 25,67 & 139,88 & 12,64 & 37,68 & 0,55 \\
\hline
\end{tabular}

Source: Author's own calculation based on demographic statistical data, Statistical Office of the Republic of Srpska 
The vitality index (Iv) is a complex, synthetic indicator of the actual and potential population biodynamics, since it is based on a synthesis between indicators of natural change in population and indicators of age structure and participation of the younger, mature population contingent, aged 20-39, in the total population (Wertheimer- Baletić, 1999).

Vitality Index exceeds value 1 in only two (2) municipalities in the Republic of Srpska. As a consequence of more prominent share of mature young population in relation to old population and fertility rates in relation to the mortality rate. the municipalities with the highest vitality index in the Republic of Srpska are: Banja Luka, Istočno Novo Sarajevo, Zvornik, Bratunac, Kotor Varoš, Milići, Čelinac.

The prolonged period of insufficient births is the primary cause of natural depopulation and deeper changes in the age structure of a population. In the latest inter-census period 1991-2019, it was estimated that the population of the Republic of Srpska decreased by 500,658 (see Table 1), with the migration component contributing about $86.37 \%$ (Pašalić, 2020).

The trend of registering natural growth has been continued. Thereby the number of births in 2018 amounted to 9,568 and was less than the number of deaths $(14,763)$. Relatively observed, it is at $-4.5 \%$, that is, the rate remained nearly unchanged compared to the year before, i.e. 2017 .

Population age structure is one of the most important demographic structures. The term elderly population refers to the age cohort of the population aged 65+. The demographic aging process is characterized by an increase in the share of elderly population and middle-aged population and a decrease in the share of young population.

The values of demographic variables confirm the significant spatial disparity of municipalities / cities of the Republic of Srpska. As expected, the highest index value is in the city of Banja Luka (185.05), whereas the lowest values are registered in the smallest of municipalities.

The basic result of demographic analysis is the creation of a synthetic indicator that will allow us to identify, evaluate and compare demographic resources. The values of this index allow identification and evaluation of the demographic resources of the Republic of Srpska (both at aggregate and lower territorial levels).

Variables for identifying and evaluating demographic resources can be divided into two main groups: 1) variables on population size, composition, and spatial distribution, and 2) variables on total or specific population contingent, as well as natural population change and migrations (Oliveira-Roca, 1991).

The above variables, together with the possible absence of some of them, are the basis for the design of synthetic demographic indicators. The Republic of Srpska is characterized by a long-term tendency of reducing the young and increasing the share of the elderly population.

Figure 5. Demographic index of municipalities and cities of the Republic of Srpska, 2018.

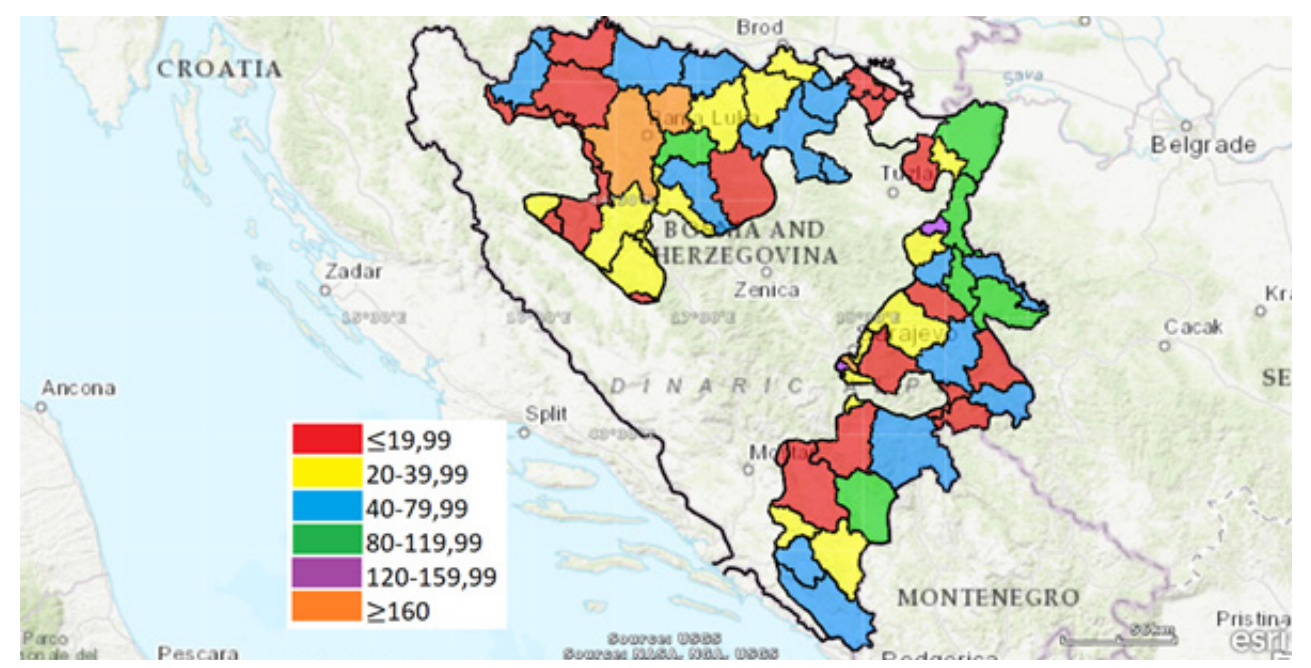

Souce: Author's own processing using GIS, based on vital statistic data, education stats and population estimate, Statistical Office of the Republic of Srpska, Banja Luka, 2019. 
According to the obtained Demographic Resources Index, the Republic of Srpska is type D (poor demographic resources), whereas the city of Banja Luka belongs to type A (extremely favourable demographic resources). The Demographic Resources Index can be used as a basis for planning and directing socio-economic development, as well as for the general valorisation of space, according to data on demographic resources and potential, as well as on the level of education. Human potential is the most important factor for demographic and economic development.

Table 4 Demographic index of municipalities/cities in the Republic of Srpska (idem)

\begin{tabular}{|c|c|c|c|c|}
\hline $\begin{array}{c}\text { Dynamic coefficient } \\
K d\end{array}$ & Share $P(o-14) / P$ & $\begin{array}{c}\text { Share of female } \\
\text { population aged } 20 \\
\text { to } 29 P_{f(20-29)} / P_{f}\end{array}$ & $\begin{array}{c}\text { Vitality Index } \\
I_{v}\end{array}$ & $\begin{array}{c}\text { Demographic } \\
\text { index: } \\
I_{D E M}=k d * P(0-14) * \\
P_{f(20-29)} * I_{v}\end{array}$ \\
\hline 0,74 & 13,54 & 11,25 & 0,55 & 62,00 \\
\hline
\end{tabular}

Source: Cities and municipalities of the Republic of Srpska, Banja Luka, 2018.

Population estimate according to age and gender, Statistical Office of the Republic of Srpska, Banja Luka, 2018.

The demographic index is derived from the coefficient of population dynamics 1991/2018), from the share of the younger population of the pre-fertile age, as well as from the share of the female population aged 20-29 and the vitality index.

Demographic index values confirm the significant spatial disparity of municipalities / cities of the Republic of Srpska. As expected, the highest index value is in the city of Banja Luka (185.05), whereas the lowest values are registered in the smallest of municipalities (Pašalić et al., 2020).

\subsection{EDUCATIONAL SYSTEM OF THE REPUBLIC OF SRPSKA}

The educational system in the Republic of Srpska consists of segments with their own specific missions, that is, the purpose of existence within a complete education and upbringing system. It is broad, well developed, complex and difficult to analyse, as well as fairly difficult for development strategy synthesis. Thus, a complete educational system is broken down into sections with specific educational missions. These sections are called educational subsystems. Their missions are derived from the mission of the education system as a whole and are mutually harmonized, whereas the functions of the education subsystem are derived from their missions.

The educational system has been decomposed into the following educational subsystems: 1 . Preschool education and upbringing; 2. Elementary education and upbringing; 3. Secondary education and upbringing (general secondary and art schools, vocational secondary schools); 4. Higher education (basic studies, master studies, doctoral studies).

The first three subsystems comprise pre-university education. All segments of the pre-university education contain development elements that are common to many of them. Likewise, all higher education segments have elements of development that are common and form the framework of higher education development.

Quality is the primary development goal at every educational level, from pre-school and doctoral studies to adult education and lifelong learning. No other goal can be achieved at the expense of quality.

From the above data, covering the nearly 20 -year post-war period, there is an evident rise in the development of preschool education and upbringing, that is, an increase in the coverage of preschool children, with a tendency of further increase. Elementary education shows a significant decline in the number of pupils, which is a consequence of a lower birth rate of certain generations. 
Table 5. School population trends throughout subject five-year periods

\begin{tabular}{|c|c|c|c|c|}
\hline Academic year & $\begin{array}{c}\text { Pre-school } \\
\text { education }\end{array}$ & $\begin{array}{c}\text { Elementary } \\
\text { education and } \\
\text { upbringing }\end{array}$ & $\begin{array}{c}\text { Secondary } \\
\text { education and } \\
\text { upbringing }\end{array}$ & $\begin{array}{c}\text { University } \\
\text { education }\end{array}$ \\
\hline $1998 / 99$ & - & 125,812 & 53,340 & 15,283 \\
\hline $2003 / 04$ & 4,618 & 125,256 & 51,577 & 21,717 \\
\hline $2008 / 09$ & 6,342 & 113,320 & 46,938 & 41,246 \\
\hline $2013 / 14$ & 7,599 & 96,932 & 46,421 & 41,988 \\
\hline $2018 / 19$ & 12,156 & 89,630 & 38,449 & 29,006 \\
\hline
\end{tabular}

Source: Demographic stats and education stats (Almanac), Statistical Office of the Republic of Srpska, Banja Luka, 2019.

However, as this segment of the educational system is mandatory by law, the coverage of generations by elementary education is satisfactory. Secondary education displays a tendency of a decline as far as the total number of pupils is concerned, that is, an insufficient coverage of generations by secondary education. Higher education has an unusual trend in the development of the student population. Obviously, the increase in the number of higher education institutions (both public and private), resulted in an increased coverage of generations by higher education. However, a decline in the number of students in higher education institutions occurred after a certain period, which, as with other educational segments, is primarily a consequence of negative demographic trends. In order to increase the coverage, relevance and efficiency of the successful completion of education process, it is necessary to establish the strategic commitments to be achieved with certain quantitative indicators of the level of achievement (educational coverage of generations).

Pre-school education - children from 6 months to 3 years of age should be granted increased access to diversified programs and services and up to $25 \%$ coverage of children of that age. Children aged 4-5 should be allowed to use quality educational programs free of charge during the school year (coverage of up to 50\%). Children ages 5-6 should have full coverage (100\%) through full-day and half-day pre-school programs.

Current coverage of children in preschool education in (2018/2019) amounts to $12.156(21,49 \%)$.

Elementary education - all children that reach the mandatory school age (minimum $99 \%$ of the generation), regardless of any and all differences, should be covered by quality basic education and upbringing, where the dropout rate should not exceed 2\%, meaning that elementary education should be completed by minimum $97 \%$ of the generation.

The current coverage of children by elementary education (2018/2019) is 89,630 (97.36\%).

Secondary education - $97 \%$ of those who have completed elementary school (also $97 \%$ of the generation) enrol in one of the secondary schools. Here it is necessary to define strategic choices about the structure, that is, the type of high schools that certain generations need to enrol with.

$35 \%$ of a generation enrols with grammar schools and general arts secondary schools, $40 \%$ of a generation enrols in a 4-year secondary vocational education course, whereas $20 \%$ of the generation enrols in a 3-year secondary vocational education course. That makes up 95\% of a generation. Bearing in mind that a secondary school, at least for the time being, is not mandatory by law, as well as a certain dropout rate for a number of reasons, the planned $95 \%$ would be the optimum to aim for. Secondary education should be obtained by a minimum of $90 \%$ of a generation.

Current secondary education coverage (2018/2019) is 38,499 (77.68\%).

Higher education - enrols at least $50 \%$ of those who have completed four years of vocational secondary education, and $95 \%$ of those who have completed grammar schools and other high schools. This means that higher education is attended by minimum $55 \%$ to $60 \%$ of a particular generation. Further, $70 \%$ of those enrolled manages to complete higher education studies in time or with a delay of one year. Of all the students who complete their undergraduate studies, $50 \%$ of them continue their education in master studies, while minimum $10 \%$ of students who obtain master's degree continue their studies through $\mathrm{PhD}$ studies. 
Current higher education coverage (2018/2019) amounts to $42.92 \%$ (student utilization index). The education index is calculated from the share of the population of tertiary education, and the share of the student population in the population aged $25+$. The correction coefficient is defined using the standard characteristic ( $\mathrm{z}$-value), expressed in units of standard deviation: $\mathrm{Io}=\mathrm{kx}$ (PoIII $\mathrm{x}$ Ss).

The Education Index (Io), as a key component in the calculation of the Demographic Resources Index, is an indicator that provides information on the attained educational level of the population observed, as well as on available potential in terms of human resources, as real drivers and carriers of economic and other forms of development in a given area.

Table 6. Education index of municipalities/cities in the Republic of Srpska, 2018

\begin{tabular}{|c|c|c|c|c|}
\hline $\begin{array}{c}\text { Student } \\
\text { utilization index } \\
\boldsymbol{S}_{s}\end{array}$ & $\begin{array}{c}\text { Total population with } \\
\text { tertiary (postsecondary) } \\
\text { education } \boldsymbol{P}_{\text {oIII }}\end{array}$ & $\begin{array}{c}\text { Population of } 25 \\
\text { and over } \\
\boldsymbol{P ( 2 5 + )}\end{array}$ & $\begin{array}{c}\text { Share of PoIII } \\
\mathbf{P}_{\text {oIII }} / \mathbf{P}_{(25+9} \mathbf{x} 100\end{array}$ & $\begin{array}{c}\text { Io= } \\
\mathbf{P}_{\text {oIII }} \mathbf{x S}_{\text {s }}\end{array}$ \\
\hline 37.32 & 92012 & 860,755 & 10.68 & 398.57 \\
\hline
\end{tabular}

Source: Population of 15 and over sorted per highest level of education

Education stats, "Higher Education" Statistical Bulletin, Statistical Office of the Republic of Srpska, Banja Luka, 2019.

Population education, i.e. educational coverage of population has been provided for the Republic of Srpska as a whole. However, highlighting the education index solely at the aggregate level represents a general picture of this condition. It is crucial that this is also observed at lower (territorial) units, i.e. local self-government units. The data provided (see map of education index of municipalities and cities of the Republic of Srpska), demonstrates disparities amongst the local self-government units, which is reflected in the economic and overall development of local communities.

The Republic of Srpska as a whole, but its local communities as well need to raise their education index, particularly since the education index is one of the components of the Demographic Resources Index, but also of the components of economic and sustainable development.

The importance of education is ever increasing in contemporary conditions as knowledge has become a key resource for the advancement of society, that is, of organization and individuals. The most profitable investments in the 21st century are considered to be investments in science and education. Developed societies are relentlessly moving in the direction of the knowledge economy.

Figure 6. Education index of municipalities/cities in the Republic of Srpska, 2018

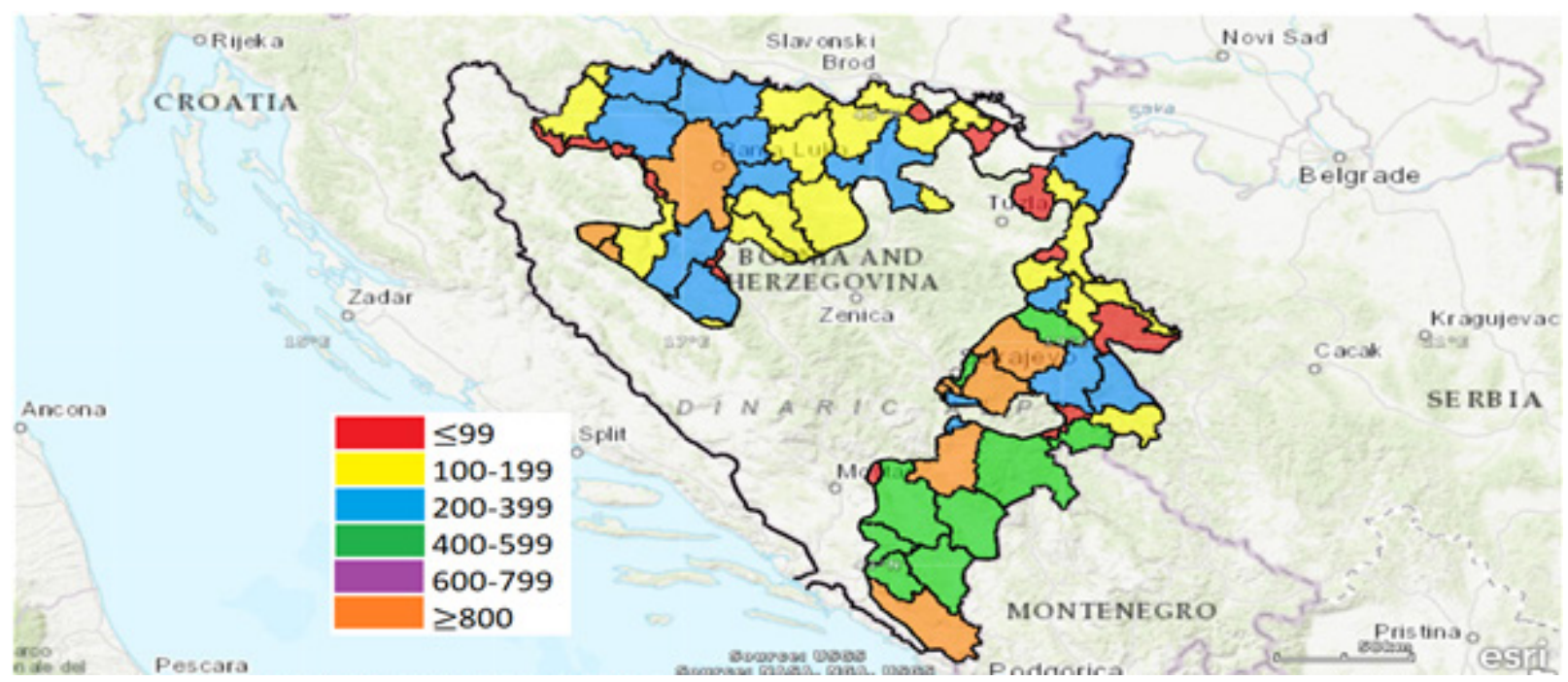

Source: Author's own processing using GIS, based on education stats and population estimate, Statistical Office of the Republic of Srpska, Banja Luka, 2019. 
Modern education plays a very important role in transforming society towards the knowledge economy. In order to fulfill this role, the development of education in several basic directions can be expected in the upcoming period. One of such key directions concerns the application of new technological advances in the educational process, but also of new teaching methods. In addition, the role of teachers and professors is changing, whereby they are requested to act as motivators, associates and advisors to students, in addition to "merely" being lecturers. Likewise, the growth of the education market, i.e. the diversification of educational institutions and study programs (at higher education institutions) can be reasonably assumed through rational arguments. The aim of these changes is to transform the educational system so that it is able to " deliver " the knowledge and skills that society will required in the upcoming period.

It is estimated that the most sought-after professions will be related to information and communication technologies. However, there will be a strong need for other occupations that are necessary to respond to changes in society. Either way, some traditional jobs will simply disappear, some will be modernized, but new creativity-based jobs and the ones based on specific knowledge and skills will eventually emerge; ones which cannot be fully automated.

Table 7. Projection of (average) educational coverage of generations (2020/21-2024/25)

\begin{tabular}{|c|c|c|c|c|}
\hline Generations & Births & $\begin{array}{c}\text { Coverage } \\
\text { per current trend }\end{array}$ & Required coverage & $\begin{array}{c}\text { Discrepancy } \\
\mathbf{3 : 4}\end{array}$ \\
\hline 1 & 2 & 3 & 4 & 5 \\
\hline $\begin{array}{c}\text { Preschool education } \\
\text { and upbringing }\end{array}$ & 53,466 & 11,602 & 25,000 & $-13,398$ \\
\hline $\begin{array}{c}\text { Elementary school } \\
\text { education and } \\
\text { upbringing }\end{array}$ & 89,966 & 85,467 & 89,066 & $-3,599$ \\
\hline $\begin{array}{c}\text { Secondary school } \\
\text { education and } \\
\text { upbringing }\end{array}$ & 43,823 & 33,743 & 39,440 & $-6,017$ \\
\hline $\begin{array}{c}\text { University } \\
\text { education }\end{array}$ & 55,771 & 23,423 & 27,885 & $-4,462$ \\
\hline Total: & 243,026 & 154,235 & 181,391 & $\mathbf{- 2 3 , 4 6 0}$ \\
\hline
\end{tabular}

Source: Author's own processing based on demographic statistical data and education stats, Statistical Office of the Republic of Srpska, Banja Luka, 2019.

It is estimated that if education would stop for only one year, it would take 10 years for the economy to remedy the main adverse effects, whereas the negative side effects would be felt throughout the following 100 years (Stanišić-Vještica, 2016).

Several fundamental trends are notable in these educational changes (European Political Strategy Centre, 2017):

New generation of teaching aids - Classical teaching has been enriched by new technologies.

Digital literacy - nowadays, pupils and students need to be digitally literate and know how to use computers. These challenges must be addressed by education, which means that digital literacy, i.e. improvement of digital literacy, will be one of the main tasks of education in the future.

Interactive teaching - the time in which the teacher talks or makes a presentation while the pupils or students passively listen is a thing of the past, since the digital age requires interaction in the teaching process.

New forms of mentoring - in the traditional education system the dominant role of the teacher was - the 'lecturer', while in modern education teachers are forced to take on additional important roles, such as the teacher as a motivator, partner, associate and advisor.

Individualized Learning - modern education involves working with smaller groups as well as 
individual dialogues between teachers and pupils / students.

Multidisciplinary and Project Approach - Changes in the contemporary world are increasingly complex, so their study requires an interdisciplinary and/or multidisciplinary approach, which would allow for easer overcoming of the barriers imposed while simultaneously leading to innovative solutions).

Diversification - Modern education is increasingly becoming widespread, i.e. it is heading towards greater diversification.

Convenience - Contemporary education is becoming more practical and insisting on a prompt 'school-to-work' transition.

Lifelong Learning - Knowledge is changing and updating rapidly in modern conditions, therefore requiring a continuous learning process to keep up with this increasingly dynamic rhythm.

\subsection{MODELS OF SCHOOL NETWORK OPTIMISATION}

The trends of declining number of students in the educational system over the past 20 years have been shown in the above sections of the paper. In the 1998/99 school year, 125,812 students attended elementary education, and in $2018 / 19$ the number was reduced to 89,630 , which is a decrease of $28 \%$, bearing in mind that a system of nine-year primary education was introduced in the Republic of Srpska from 2003/2004, meaning that an additional generation was introduced into the system. If the above fact is taken into account, then the drop in the number of students is even more severe (more than 10,000). The downward trend in the number of students is present in the secondary education as well.

Twenty years before there were 53,340 students and in 2018-2019 the number dropped to 38,449 students, which is a decline of $28 \%$, i.e. 14,891 . Higher education features a different trend in the number of students. Since 2005, after the establishment of numerous private higher education institutions, there has been a significant increase in the number of students, the maximum of which was in 2011, amounting to more than 46,000 students. Ever since, there has been a steady decline in student numbers, despite the increase in the number of higher education institutions (21 in total). The downward trend in the number of students is to be continued, which is primarily a consequence of demographics, but of other factors as well (e.g. studying outside the Republic of Srpska, etc.).

The trend of overall decrease in the number of pupils and students was not simultaneously accompanied by a corresponding adjustment of the number of school facilities.

That is why it is necessary to consider rationalization, that is, optimization of school network (primarily of elementary education and upbringing), but also to consider the option of introducing classes with a small number of pupils (in accordance with pedagogical standards). Why is the above important in the educational system at all? Primarily, economic rationality is always the initial starting point, however, there are other factors as well, such as whether the existing network is economically viable, i.e. the entire public sector from the aspect of economic sustainability, including education.

Namely, if saving and reducing the number of employees in the public sector is an imperative, the question is how to implement the rationalization (optimization) of the educational system without harming the quality and accessibility of education.

One on the solutions would be to rationalize (or optimize) the school network. The rationalization of the school network implies the creation of such network that is economically maximally rational from the aspect of cost-benefit analysis. Optimization of the school network includes the reconstruction of the school network both in the medium and long term, for the purpose of generating a network that would guarantee relevant education of maximum quality for all children, with maximum consideration for economic rationality and economic opportunities. where demographic trends and migration trends are the key to managing the school network and planning decisions on the 
status changes and purpose of the facilities the teaching process takes place in. In this case and in earlier cases, facilities of the schools that have been "shut down" should be used for other needs of the educational system, or for the sake of other public services. The problem of insufficient space for pre-school education is obvious today, with the increasing coverage of children in this segment of education, whereas new kindergartens have been built although there were already half-empty schools in some of those areas. Simultaneously, due to the influx of population, it was necessary to build new schools in some areas (Banja Luka, Bijeljina, etc.). Therefore, it can be said that the educational system is only resilient when it is necessary to perform an increase, but that there are no changes in cases where it is necessary to abolish or terminate certain institutions and change their purpose. The problem becomes even more evident if the educational system is viewed integrally rather than partially.

Upon summarizing the aforementioned problems, it is possible to define certain models of the school network optimization (primarily of elementary schools), which would have a positive effect on the state budget and the budget of local communities (material costs).

School closure was applied in earlier periods of school network development but was never designed in a systematic manner. This model should be applied when it is not possible to apply any other. The key parameters for this model would be demographic indicators, if there are no new pupils being enrolled in a school or if there are only a few of them, with the need to convert the facilities used by a particular school.

A model of termination of legal entity status and merger-absorption of a small school by another larger school, with the continuation of the teaching process in the facilities of the "terminated" school.

Likewise, it is possible to established a so-called grouping of certain administrative (non-teaching) activities at the local community level, which would be a form of a "consolidated" or "unified" school in which all administrative and financial affairs of certain elementary schools take place.

It is also possible to contract non-teaching activities (cleaning of school facilities, administrative and financial affairs, etc.) by transferring them to the private sector by contracting mutual rights and obligations, thus reducing the total number of school employees. However, it is not possible to find a unique universal model for all local communities, but it is necessary for each local community to assess the specifics and opt for the model that suits them best.

The newly introduced Law on Higher Education also foresees the establishment of a network of higher education institutions in the Republic of Srpska, which is a novelty, and will be based on the conditions and needs of the Republic of Srpska.

In short, the goal is to keep the development of these models in line with the developmental rather than restrictive concept of optimizing the school network in the Republic of Srpska. More details about the models can be found in the study "Demographic development of the school population and the optimization of the school network in the Republic of Srpska" by Prof. Stevo Pašalić and Prof. Proko Dragosavljević (2007).

Table 8. Students, classes and teachers in elementary education the Republic of Srpska, 2018/2019

\begin{tabular}{|l|l|l|l|l|l|}
\hline & $\begin{array}{c}\text { Number of } \\
\text { students }\end{array}$ & $\begin{array}{c}\text { Number of } \\
\text { classes }\end{array}$ & $\begin{array}{c}\text { Average } \\
\text { number of } \\
\text { students }\end{array}$ & \multicolumn{1}{|c|}{ Teachers } & Median age \\
\hline Total & 89,630 & 4.973 & 18 & 8,148 & 38.3 \\
\hline I-V & 50,123 & 2,958 & 16.9 & 3,259 & 38.1 \\
\hline VI-IX & 39,507 & 2,021 & 19.5 & 4889 & 38.5 \\
\hline
\end{tabular}

Source: Author's own processing based on education stats data, Statistical Office of the Republic of Srpska, Banja Luka, 2019 
Alongside with the continued decline in the number of pupils and classes, the number of teachers is increasing slightly, with a particular increase in part-time teachers compared to previous years. This is understandable, given the reduction in the number of classes and the lower average number of pupils in the classes. It should be mentioned that there are 765 combined classes (742 in class teaching and 23 in subject teaching) in the total number of classes, whereby the average number of students in such combined classes amounts to 8.4.

It is evident that the teaching staff in elementary education is relatively young, which suggests that the shift of generations of teachers has ended (the so-called baby boom generations' careers have ended). On the other hand, this would mean that there is now significantly less room for recruitment of new teachers, which is very important from the aspect of the staff training planning at teacher training universities.

In higher education, the Republic of Srpska has 1,167 full-time teachers, and 1,407.7 teachers in full-time equivalent, i.e. 2,810 teachers and associates, whose median age is 45.2 years. In relation to the total population that is 0.101. In the Federation of Bosnia and Herzegovina, that number is 0.196. Therefore, this is an unfavourable coefficient. Despite the constant decrease in the number of students, it is evident that the Republic of Srpska has yet to achieve a satisfactory number of teachers in higher education. In addition, the number of students per teacher in the Republic of Srpska is about 25, whereas the normal standards are about 15 (fifteen).

\subsection{EDUCATIONAL SYSTEM OF THE REPUBLIC OF SRPSKA FOR A MORE DEVELOPED SOCIETY}

At the beginning of the 21st century, analysts predicted that, as a result of a prolonged decline in fertility rates, Europe's population would diminish by $6 \%$ over the next 25 years, and that by mid21st century, Europe's share of the world population would tend to decline steadily (UN, 2001).

About $10 \%$ of the world's population lives in Europe today, and given the expectation that the average annual population growth rate will be negative in the next three to four decades, it is projected that between $7 \%$ and $8 \%$ of the world population will inhabit Europe by 2050 (UN, 2011). As a result of the decline in fertility rates, population aging will continue, and in the long term once the birth rate stabilizes, a continuous decrease in the mortality rate will become a cause of population aging (Coleman, 2006, 19).

The situation in Eastern and South-eastern Europe is particularly difficult, as they are to suffer rapid population decline, apart from low fertility and emigration conditions. Such trends are, in themselves, very problematic, particularly given the fact that some of the countries from this region missed the opportunity to utilize their earlier, somewhat atypical demographic trends.

By the middle XXI century, the proportion of 65+ year olds in Eastern and South-eastern Europe will increase to between $26 \%$ and $33 \%$ (Coleman, 2006, 19). Once it happens, the difficulties in terms of efficiency and competitiveness will be made even more difficult by the aforementioned aging, but also as a consequence of the decrease in the working age population.

Given the disadvantages of the current demographic situation, it is quite logical to reconsider the potential for mitigating their negative impulses for economic growth.

Indicatively, the solutions can be divided into demographic and non-demographic (Coleman, 2006). The choice of demographic solutions has been narrowed down to increase fertility and boost immigration. In particular, in order to simply maintain the current level, the overall fertility rate in Europe would have to increase to 3.5 , which is an impossible option. Is it possible to compensate the population deficit caused by the low birth rate by means of migrations of younger populations? The effects of immigration movements seem not to be so ample, because if the current situation is to be maintained, an average of 25 million people a year would have to migrate to Europe, which is not a realistic option (Coleman, 2006).

In some parts of South-eastern Europe (Western Balkans), the situation is even more complicated, 
as these countries are economically underdeveloped and are not considered as an attractive area for immigration. Therefore, as there are no demographic solutions for the aging population, it is necessary to resort to non-demographic responses (solutions) related to improvements in education, adjustment to the labour market, and extending the retirement limit in the pension system. Increasing investment in the education of working-age population is a significant determinant with exclusively positive effects on economic growth (Lutz et al, 2008).

Assuming that the global education scenario is realized, i.e. implementation of future enrolment trends (transitions to higher education categories) in each country, the educational profile of the workforce will undoubtedly improve. If labour inputs are to continue declining as a result of technological change, such combination of fewer but better educated workers can have a stimulating effect on increasing labour productivity, which is precisely what European countries (as well as the Republic of Srpska) require.

In addition, less developed countries generally face the problems of unreformed labour markets and pension systems, and, as a rule, those countries that are in the poorest demographic position usually face the greatest institutional difficulties (Jackson \& Howe, 2003).

This could entail certain initiatives to improve or increase the workforce share, such as by increasing the women participation share in the workforce, shortening the studies duration (in terms of increasing efficiency), earlier employment, and by modifying the mandatory and developing a voluntary pension system.

A synthetic indicator is the Demographic Resources Index (ider) - according to which, the Republic of Srpska is classified as type D, of poor demographic resources, with weakened demographic characteristics and potentials and generally low level of education.

The conclusion is that according to the population estimation data (Statistical Office of the Republic of Srpska, 2018), demographic sustainability is no longer ensured, neither quantitatively nor qualitatively, in $30 \%$ of municipalities, mostly those featuring low population numbers.

Table 9. Demographic resource index

\begin{tabular}{|c|c|c|c|}
\hline $\begin{array}{c}\text { Demographic index: } \\
\boldsymbol{i}_{\text {DEM }}\end{array}$ & Education index: $\boldsymbol{i}_{\boldsymbol{o}}$ & $\begin{array}{c}\text { Correlation coefficient: } \\
\boldsymbol{k}\end{array}$ & $\begin{array}{c}\text { Demographic resource } \\
\text { index: } \mathbf{i}_{\text {der }}=\mathbf{k}^{*}\left(\mathbf{I}_{\text {DEM }}+\mathbf{I}_{\mathbf{O}}\right)\end{array}$ \\
\hline 62.00 & 398.57 & 0.026 & 11.97 \\
\hline
\end{tabular}

Source: Cities and municipalities of the Republic of Srpska, Population estimate according to age and gender, Statistical Office "Higher Education" Statistical Bulletin, Statistical Office of the Rep. of Srpska, Banja Luka, 2019.

In second group, comprising 38\% of municipalities / cities, the sustainability is possible, although the level of human assets development is rather poor. On the other hand, municipalities / cities, which are in the first three categories by type, and somewhat in the fourth, are demographically sustainable.

For a demographic analysis, it is necessary to compare the results of the development index (the level of development of municipalities and cities of the Republic of Srpska) with the results of the Demographic Resources Index both for the Republic of Srpska and for its municipalities and cities. The included Figure No.7, shows that the municipalities and cities of the Republic of Srpska have been classified into 6 types based on the Demographic Resources Index.

Therefore, the Republic of Srpska is, like the entire region of Southeast Europe, interesting in many ways, as the number of inhabitants in the World maintains a steady increase (7.79 billion), in Southeastern Europe and in the rest of Europe it is declining. The projection is that the world population will reach about 9 billion people in 2050, whereas our region will continue to decline in numbers. The paper is mostly interested in reflecting these unfavourable trends on economic trends as well as on the future of the Republic of Srpska. 
Figure 7 Demographic resource index of municipalities and cities of the Republic of Srpska, 2018.

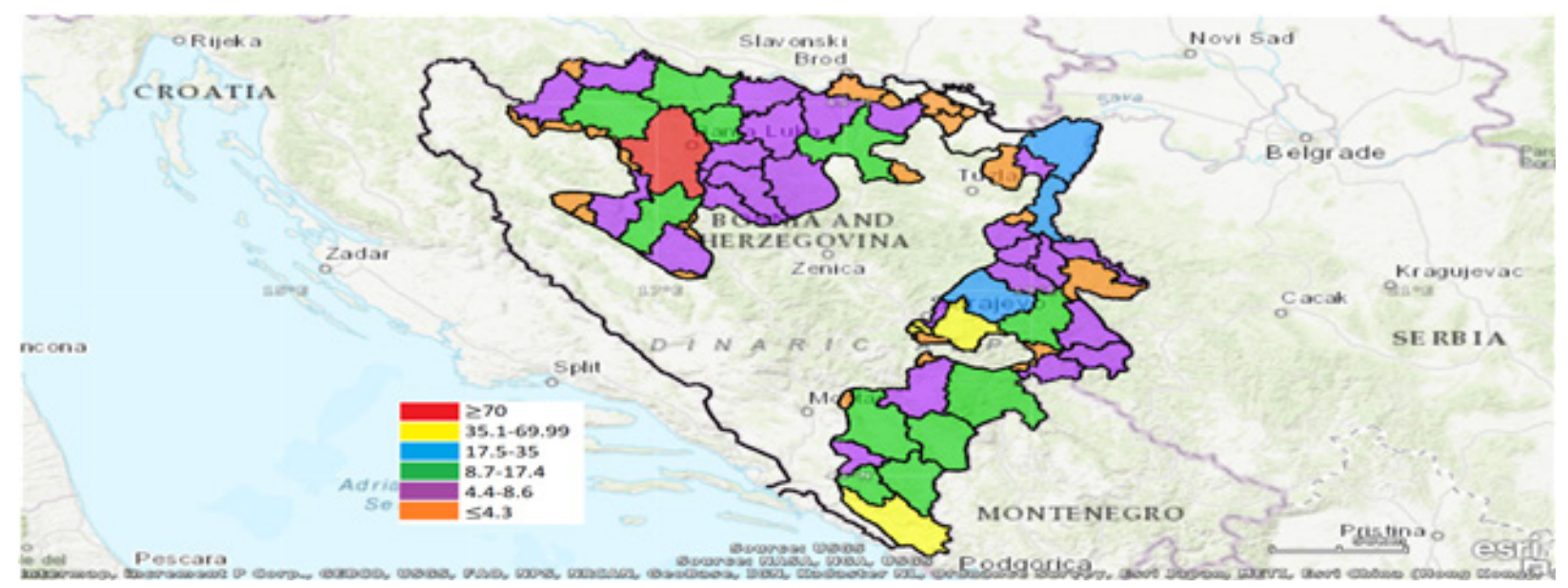

Source: Author's own processing using GIS, based on vital statistic data, education stats and population estimate, Statistical Office of the Republic of Srpska, Banja Luka, 2019.

The established demographic "snapshot" of the situation and the typology produced may serve as a useful source of information for understanding and monitoring complex demographic phenomena and processes, as well as for formulating population development policy methods aimed at mitigating the effects of a troubling demographic situation.

Table 10. Grouping municipalities/cities according to Demographic resource index values

\begin{tabular}{|l|c|}
\hline Municipalities/cities & Type \\
\hline Banja Luka, (1) & A \\
\hline Istočna Ilidža, Istočno Novo Sarajevo, Pale, Trebinje (4) & B \\
\hline Bijeljina, Sokolac, Zvornik (3) & C \\
\hline $\begin{array}{l}\text { Bileća, Gacko, Gradiška, Doboj, Laktaši, Ljubinje, Mrkonjić Grad, Nevesinje, Prijedor, Rogatica, } \\
\text { Foča (11) }\end{array}$ & D \\
\hline $\begin{array}{l}\text { Berkovići, Bratunac, Višegrad, Vlasenica, Derventa, Istočni Stari Grad, Kalinovik, Kneževo, } \\
\text { Kotor Varoš, Kozarska Dubica, Novi Grad, Milići, Modrića, Prnjavor, Ribnik, Rudo, Srbac, Teslić, } \\
\text { Ugljevik, Han Pijesak, Čajniče,Čelinac, Šekovići, Šipovo (24) }\end{array}$ & E \\
\hline $\begin{array}{l}\text { Brod, Vukosavlje, Donji Žabar, Istočni Drvar, Istočni Mostar, Jezero, Kostajnica, Krupa na Uni, } \\
\text { Kupres, Lopare, Novo Goražde, Osmaci, Oštra Luka, Pelagićevo, Petrovac, Petrovo, Srebrenica, } \\
\text { Trnovo, Šamac (19) }\end{array}$ & F \\
\hline
\end{tabular}

${ }^{\star}$ Stanari - incomplete data

Population is important, but a factor that is even more important than sheer quantity is the ability of an individual (its quality), and countries that focus on a human development index that attracts talent, even in the context of low fertility.

It is clear that the time to maintain the population of the country by means of a population policy has long passed, and that the factors such as human resources, innovation and productivity are playing an increasingly important role.

The best method of resolving the problem of population reduction is essentially to create preconditions for people to have confidence in building their own country and future therein, which is a key factor to stopping population decline. Thus, if people, particularly young people, have access to quality education and health care, if they are provided with stable jobs and are given an incentive to raise children, they are less likely to emigrate and more likely to decide to have children in their own country. In this context, we should once again observe the level of generational reproduction of the population in the Republic of Srpska. 
Of particular concern is the fact that according to the projections of the population of Srpska, the population aged $25-30$ is declining, by as much as $25 \%$. At the same time, there is a significant increase in the number of people over 60 who are considered to be a low active or even inactive part of the population. In doing so, one forgets that a pronatalist policy acts as an incentive to "produce" the future workforce.

Ultimately, analyses show that the demographic deficit is probably our most important, most difficult and most far-reaching structural issue.

\section{CONCLUSION}

The issue of demography is a strategic national issue for the future of the Republic of Srpska and the cornerstone of its overall development.

The childbirth level is well beneath the level required for a mere replacement of generations, a period which has lasted for almost two decades and is the main driver of the depopulation and noticeable aging of the population of the Republic of Srpska.

The Republic of Srpska is one of the areas where the demographic aging process has reached a considerable scale. The results of the projections indicate that the process of population aging will continue throughout the first half of the 21st century and that the number of persons aged 65 or older in the Republic of Srpska will increase by a third by 2050, whereas their share in the total population will increase depending on the scenario, ranging from $18.7 \%$ to $27.5 \%$.

From an economic standpoint, the impact of age structure of a population on the workforce economic structure is of particularly importance. The size of the labour contingent, within which most of the labour supply is formed in modern conditions, is in continuous decline in the Republic of Srpska.

The economic dependence ratio, as a ratio of dependents and population with personal income to economically active population, is increasing. Adverse changes in age composition are reflected in the workforce as well. The share of the younger generations is decreasing while the share of the older ones is on the increase.

Demographic changes will pose a major challenge for policy makers and to the society in general across the upcoming decades and will require shaping new economic, tax, health, pension, educational, social, family and other policies that affect demographic changes.

Not all of the depopulation areas in the Republic of Srpska can be revitalized, nor is such action necessary. Areas with economic and social infrastructure play a key role in retaining indigenous population. These areas should play a key role in initiating economic development. In order to retain and even attract the population, among other things, an appropriate educational system should be designed in accordance with the economic structure of the area.

Demographic trends in the Republic of Srpska are most directly reflected onto the educational system, particularly in the quantitative sense (a decrease in the number of individuals in a generation due to less births and increased emigration).

Education is the basis of development and a source of power of any society. Its role is so significant that the new, current phase in social development is often referred to as the 'knowledge economy'. This phase is significantly different from the period first dominated by agriculture and then by industry. Differences are not only manifested by the technology that is applied, but also by radical changes in the attitude towards knowledge and acceptance of new values and rules in a society. These changes are developed into several key directions of affirmation of lifelong learning: the application of modern technologies in the teaching process, the increased importance of digital literacy, as well as the modernized role of teachers. Therefore, it can be concluded that the society, and primarily the economy will be further developed by education. These changes are driven by global demographic and socio-economic factors, and particularly by the dynamic development of technology. 
In the upcoming period, education is expected to meet the growing needs of society for new occupations. Most of these occupations are related to information and communication technologies (developers, system engineers, network architects, virtual security experts, integrated digital media specialists, etc.). There will also be a need for other occupations, such as organic chemistry specialists, medical professionals specializing in the treatment and care of the elderly, climate change and environmental protection occupations. All of the above poses extremely complex challenges to the educational system, as education is expected to rapidly adapt to the new state of reality.

The aim is to provide a stimulating learning environment and quality programs for generations in the Republic of Srpska in order to enable them to apply the knowledge they have acquired upon graduation.

Unless unforeseen events happen globally, the international dimension of higher education will remain extremely significant, while its importance will continue to expand in national and regional higher education systems across the world. The key challenge in the future of higher education, in the context of globalization and internationalization, will be the establishment of internationally recognized quality standards, thereby allowing higher education to continue developing its international dimension.

\section{REFERENCES}

Coleman, D. (2006). Europe's Demographic Future: Determinants, Dimensions and Challenges. Retrieved January 30.

Jackson, R., \& Howe, N. (2003). The 2003 Aging Vulnerability Index. Washington, D.C: Centre for Strategic and International Studies and Watson Wyatt Worldwide. Retrieved 30 January 2012, from http://csis.org/files/media/csis/pubs/aging_index.pdf

Lutz W. et al (2002), Population and environment, Population Council, New York.

Maroco, J. (2003), Análise estatística - com a utilização do SPSS, Edições Sílabo, Lisboa.

McKendrick, H. J., 1999: Multi-Method Research: An introduction to its Application in Population Geography, The Professional Geographer No. 51 (1), pp. 40-50.

Nejašmić, I. \& Mišetić, R. (2010). Sintetički pokazatelji demografskih resursa: doprinos tipologiji hrvatskog prostora (eng. A Synthetic Indicator of Demographic Resources: Contribution to the Typology of Croatian State Territory). Croatian Geographical Bulletin, No.72(1), pp. 49-62.

Pašalić, S. (2010), Demografski kontigenti mlade populacije Republike Srpske - izazov za visoko obrazovanje (eng. Demographic Contingents of the Young Population in the Republic of Srpska - a Challenge for Higher Education), The International Scientific Meeting, Divčibare, Bulletin of the Serbian Geographical Society No.4

Pašalić, S. (2012), Projekcije razvoja mlade (školske) populacije u Republici Srpskoj iz demografske perspektive (eng. Development Projections of the Young (School-Age) Population in the Republic of Srpska from a Demographic Perspective), Bulletin of the Antrhopological Society of Serbia, Niš

Pašalić, S. (2012). Demographic Losses in Bosnia and Herzegovina 1991-2011. Republic Center for war crine research, the Hague: ICTY

Pašalić, S. (2015). Društveno-ekonomske posljedice budućih demografskih kretanja u Republici Srpskoj (eng. Social and Economic Consequences of Future Demographic Trends in the Republic of Srpska), Novi ekonomist No.17. Bijeljina: Faculty of Business Economics

Pašalić, S., Dragosavljević, P. (2007). Demografski razvoj školske populacije i optimalizacija mreže škola u Republici Srpskoj (eng. Demographic Development of School Population and Optimization of School Network in the Republic of Srpska), Banja Luka: Government of the Republic of Srpska - Ministry of Family, Youth and Sports

Pašalić,S. et al. (2014). Demografski resursi i organizacija osnovnog obrazovanja u Republici Srpskoj (eng. Demographic Resources and Organization of Elementary Education in the Republic 
of Srpska), Bulletin of the Antrhopological Society of Serbia, Novi Sad

Pašalić, S., Mandić, R. (2015). Posljedice budućih demografskih promjena u Republici Srpskoj (eng. Consequences of Upcoming Demographic Changes in the Republic of Srpska), Volume 10. Medical Sciences Department, Banja Luka:

Pašalić S. and Pasalic D. (2016). Migration Losses in Bosnia and Herzegovina and Demographic Aging, IJASOS- International E-Journal of Advances in Social Sciences, Vol.II, Issue 6, December 2016.

Pašalić, S. et al. (2017). Populaciona politika u obrazovanju Republike Srpske (eng. Population Policy in Education of the Republic of Srpska), University of East Sarajevo, Faculty of Pedagogy Pašalić, S. et al. (2020). Republika Srpska - demografski resursi, prostorni razvoj i demografska održivost, Univerzitet u Istočnom Sarajevu, Pedagoški fakultet (eng.The Republic of Srpska Demographic Resources, Spatial Development and Demographic Sustainability), University of East Sarajevo, Faculty of Pedagogy, Center for Population Education, Growth and Child Development (study)

Rencher, A.C. (2002), Methods of multivariate analysis, A John Wiley \& Sons, Inc., New York. Roca, M. N. O., Leitão, N. (2006), Sustentabilidade demográfica e desenvolvimento dos concelhos portugueses, GeoINova, Revista do Departamento de Geografia e Planeamento Regional, $\mathrm{n}^{\mathrm{o}} 12$.

Roca, M. N. O. (2011) Os Novos Rurais da Beira Interior: (Potenciais) Agentes de Desenvolvimento Local, Seminário Ibérico "Combate à Desertificação, Abandono Rural e Despovoamento Intrvenções Raianas”, Idanha-a-Nova, 20 e 21 de Janeiro de 2011

Stanišić-Vještica (2016). Uticaj obuke i obrazovanja na performanse organizacije i zadovoljstvo zaposlenih (eng. Impact of training and education on organizational performance and employee satisfaction), Belgrade: Union University (doctoral thesis)

United Nations. (2001). World Population Prospects: The 2000 Revision. Retrieved January 30. United Nations. (2011). World Population Prospects: The 2010 Revision. Retrieved January 30.

Wertheimer-Baletić,A, 1999: Stanovništvo i razvoj (eng. Population and Development), Mate, Zagreb

Sources: Agency for Statistics of Bosnia and Herzegovina. Bosnia and Herzegovina Census in 2013, Sarajevo, 2016, Banja Luka, 2016.

Statistical Office of the Republic of Srpska, Demographic Bulletins 2014-2018, Banja Luka, 2019. Statistical Office of the Republic of Srpska. The Republic of Srpska-Census in 2013.

Statistical Office of the Republic of Srpska. The Republic of Srpska - Census, Banja Luka, 2013.

Strategic plan 2016-2020 - European Political Strategy Centre, Strategic plan for the European Political Strategy Centre, setting out the department's vision for 2016-2020. 